Article

\title{
Phosphorus Removal with Coagulation Processes in Five Low Buffered Lakes-A Case Study of Mesocosm Research
}

\author{
Michał Łopata *(D), Renata Augustyniak, Jolanta Grochowska, Katarzyna Parszuto and \\ Renata Tandyrak \\ Department of Water Protection Engineering, University of Warmia and Mazury in Olsztyn, \\ Prawocheńskiego 1 Street, 10-720 Olsztyn, Poland \\ * Correspondence: michal.lopata@uwm.edu.pl; Tel.: +48-89-5233704
}

Received: 20 July 2019; Accepted: 27 August 2019; Published: 30 August 2019

check for updates

\begin{abstract}
This research deals with the impact of aluminum coagulants, used as a tool for the rehabilitation of water bodies, on changes in the phosphorus content in lakes with low alkalinity of water. Mesocosm scale experimental investigations in situ using polyaluminium chloride were carried out, based on five lakes with different levels of water buffering capacity $\left(<1.0-2.5 \mathrm{meq} \mathrm{L}^{-1}\right)$. The research was accomplished using three coagulant doses (half a dose, a whole dose, and a double dose calculated for phosphorus inactivation in a lake ecosystem). The results were compared with the ones from the control mesocosms. The study was carried out in two consecutive years. It was shown that the effectiveness of phosphorus removal from a water column was related to the dose of the coagulant, $\mathrm{pH}$ value, and the content of organic compounds. The lowest treatment effectiveness was found for lakes, with the most severe symptoms for dystrophy, which were abundant with humic compounds. As the water alkalinity increased, so did the ability of the coagulant to adsorb phosphorus, while the ecosystem's load of aluminum in toxic forms decreased. Doubling the standard dose did not result in a noticeable improvement in the water quality. The results allow us to evaluate the chances of successful lake restoration by applying aluminum coagulants to natural water bodies which are susceptible to acidification.
\end{abstract}

Keywords: lake restoration; phosphorus inactivation; alkalinity; mesocosms; coagulation; aluminum

\section{Introduction}

The protection and restoration of lakes is increasingly important in countries with limited water resources. The low resistance of these ecosystems to the input of pollutants, especially nutrients, and the growing anthropopressure induce progressive degradation at an increasingly frequent rate [1-3]. In general, the first response to excessive accumulation of nutrients in a lake (particularly phosphorus and nitrogen salts) is an increased rate of primary production processes. The earliest manifestation consists of more intensive expansion of the littoral vegetation, which, as a rule, deteriorates the recreational use of lakes, whose shores are now overgrown by plants. A more intensive influx of nutrient salts is also conducive to the expansion of phytoplankton. It is estimated that a supply of $1 \mathrm{mg}$ of phosphorus can induce a growth of algal fresh biomass of about 1000-2000 $\mathrm{mg}$ [4]. The excessive growth of algae causes harmful consequences to the environment. The transparency of the surface water suffers, and the processes of photosynthesis in deeper layers of water are disturbed. The biomass of phytoplankton settles down on the lake bed, where it undergoes mineralization, which in turn leads to oxygen deficits. When the mineralization of organic matter is incomplete, the rate of accumulation of bottom sediments increases. This aggravates the problem of maintaining oxygen balance and favors 
the well-documented $[1,4,5]$ process of the internal release of nutrients previously accumulated in sediments back into the lake. The lake's capacity to self-purify becomes depleted and the lake enters the stable turbid state of water (advanced stage of eutrophication, i.e., hypertrophy). The consequences for the natural environment of extreme hypertrophy are, first and foremost, the degradation of habitats for valuable species and depressed biodiversity. Economic consequences include the loss of valuable sources of potable and industrial water, as well as worsening the recreational assets of a lake.

The problems mentioned above appear on a global scale. Many countries, especially developed ones, have undertaken a search for legal solutions that would prevent the causes of eutrophication of surface water bodies. An example is the European Union Directive number 2000/60/EC (Water Framework Directive) [6], which sets guidelines for water policies conducted by member states, so as to achieve environmental goals. As for lakes, these goals are defined as maintaining or achieving 'good ecological status', corresponding to the natural, low level of eutrophication. One of the tools to reach environmental goals is to implement strict laws concerning the discharge of pollutants from sectors of the economy (municipal economy, industries, agriculture) to waters and to soil. In practice, it is estimated that such legal solutions bring about some improvement, but the condition of lakes in many parts of Europe is still far from satisfactory [7].

Monitoring data reported by environmental services have revealed the severity of the problem. For example, according to the Organisation for Economic Co-operation and Development (OECD) [8], the water quality of more than half of the lakes in Poland ( $66 \%$ of all natural and $55 \%$ of all artificial lakes) was below "good ecological status", as defined in the Water Framework Directive.

The above data indicate that conservation of the welfare of lakes needs intensive preservation measures, especially some reduction of the external load of pollutants from the lake's catchment. However, in many cases, the degradation is so advanced that a given lake needs restorative work. Among lake restoration methods, there is one that relies on phosphorus inactivation via the in situ application of coagulants, including aluminum salts. Aluminum or iron chlorides and sulphates are commonly used to limit phosphorus concentrations in wastewater $[9,10]$. These chemicals are also used in some waterbodies to improve the surface water quality by decreasing its phosphorus content [11,12]. It is estimated that this method has been implemented worldwide in more than 200 cases (mainly in the USA), but the effectiveness of the treatments has not always been satisfactory, especially when the reduction in external load was inadequate [13]. For instance, Jensen et al. [13] reported that among six lakes recently (2001-2009) submitted to phosphorus inactivation with the use of aluminium, the water quality was improved in all cases, but lasting outcomes were achieved in only two lakes (Nordborg Lake, 56 ha, and Glumso Lake, 25 ha). A study conducted on three morphometrically different lakes in the Czech Republic (Machovo 284 ha, Plumov 68 ha, Nove Mlyny 4 ha), submitted in 2005-2007 to restoration using polyaluminium chloride [14], demonstrated evident improvements in water quality and a lack of permanent negative environmental consequences in all cases. In Poland, the best known and documented case of successful restoration of a lake with an application of aluminium salt is that of Długie Lake (26 ha). The coagulant added to this lake in 2001-2003 (in total, 60 metric tons of a preparation containing 9\% of aluminium) led to a distinct and lasting improvement in lake quality $[15,16]$. The transparency of lake water increased to a few meters, the underwater meadows were reconstituted, and the phytoplankton biomass was greatly reduced. An ecological effect of the restoration of the natural habitat in this lake consisted of the appearance of charophytes Nitella flexilis-species which are sensitive to eutrophication, and which occur in clean waters [17]. However, $\mathrm{Al}$ application is limited mainly to lakes with well-developed buffer capacities, rich in calcium and magnesium salts, and resistant to acidification. There is a risk of the negative impact of aluminum coagulant on living organisms if it is used in soft-water lakes (with low alkalinity); hence, such water bodies are not normally subjected to reclamation by this method. 
In Europe, low-alkalinity lakes do not dominate, but they are quite common. For example, there are 592 lakes in Poland (over $8 \%$ of all Polish lakes) which are classified as being potentially at risk of acidification, with calcium levels below $35 \mathrm{mg} \mathrm{L}^{-1}$ [18]. Most European lacustrine ecosystems sensitive to acidification are located in the countries of Northern Europe. Many of these lakes are of great ecological importance, as they are habitats for wildlife species protected by law. Maintaining their good ecological status is desirable because these lakes have an unquestionable value in the natural environment. They are also a valuable natural resource for regions whose economy is based on tourism.

Considering the great variability of biotopes within this group of lakes, it can be assumed that at least in some cases, an external dose of aluminum (the element which is the most abundant metal in the lithosphere [19]) might be an acceptable restoration measure. Where applicable, this phosphorus inactivation method would not depreciate the environment populated by hydrobionts.

The aim of this study was to determine the possibility of removing phosphorus from the water in lakes with low alkalinity using polyaluminum chloride. This paper presents the results of a two-year experiment conducted in mesocosms constructed in five lakes. This study is part of a larger research project, whose main goal is to assess changes in the environment of lakes with low-alkalinity water induced by the use of aluminum salts. The results are intended to allow us to evaluate the possibility of implementing a lake restoration method using aluminum coagulants in natural lakes that are susceptible to acidification.

\section{Materials and Methods}

\subsection{Study Sites}

Five lakes in the Olsztyn Lake District were selected. These lakes, with water vulnerable to acidification, have been receiving water with high phosphorus content from anthropogenic activity. The main morphometric and hydrochemical features of the lakes are collated in Table 1. Water samples were taken five times at approximately equal intervals in the April-October period. This made it possible to obtain representative results of water chemistry, taking into account the natural cycle of the lake in a temperate climate (spring water mixing, summer stagnation, and autumn turnover). The location and bathymetric plans of the lakes are shown in Figure 1. All the lakes were similar in terms of the content of biogenic salts (phosphorus $0.07-0.14 \mathrm{mg} \mathrm{L}^{-1}$, nitrogen $1.2-1.8 \mathrm{mg} \mathrm{L}^{-1}$ on average), which is conducive to progressive eutrophication.

Table 1. Summary of the most important morphometric parameters and physicochemical properties (surface water: mean $\pm \mathrm{SD}, n=5$ ) of the surveyed lakes, based on test results obtained in the first year of the study.

\begin{tabular}{|c|c|c|c|c|c|}
\hline Parameter/Lake & Kluka Mała & Kluka Duża & $\begin{array}{l}\text { Zbiornik } \\
\text { Zachodni }\end{array}$ & Podkówka & Redykajny \\
\hline \multirow{2}{*}{ Location } & $\mathrm{N} 53^{\circ} 41^{\prime} 00^{\prime \prime}$ & $\mathrm{N} 53^{\circ} 41^{\prime} 02^{\prime \prime}$ & $\mathrm{N} 53^{\circ} 41^{\prime} 08^{\prime \prime}$ & $\mathrm{N} 53^{\circ} 48^{\prime} 16^{\prime \prime}$ & $\mathrm{N} 53^{\circ} 48^{\prime} 52^{\prime \prime}$ \\
\hline & E $20^{\circ} 25^{\prime} 59^{\prime \prime}$ & E $20^{\circ} 25^{\prime} 35^{\prime \prime}$ & E $20^{\circ} 25^{\prime} 05^{\prime \prime}$ & E $20^{\circ} 27^{\prime} 02^{\prime \prime}$ & E $20^{\circ} 25^{\prime} 04^{\prime \prime}$ \\
\hline $\begin{array}{l}\text { Surface area (ha) } \\
\text { /max depth (m) }\end{array}$ & $3.4 / 4.1$ & $11.3 / 5.7$ & $4.0 / 7.0$ & $6.9 / 6.0$ & $29.9 / 20.6$ \\
\hline Trophic status & $\begin{array}{l}\text { dystrophy } \\
\text { /eutrophy }\end{array}$ & $\begin{array}{l}\text { eutrophy } \\
\text { /dystrophy }\end{array}$ & $\begin{array}{l}\text { dystrophy } \\
\text { /eutrophy }\end{array}$ & $\begin{array}{l}\text { eutrophy } \\
\text { /dystrophy }\end{array}$ & $\begin{array}{c}\text { eutrophy } \\
\text { /mesotrophy }\end{array}$ \\
\hline Alkalinity (meq $\left.\mathrm{L}^{-1}\right)$, & $0.69 \pm 0.18$ & $0.48 \pm 0.05$ & $0.45 \pm 0.06$ & $1.73 \pm 0.10$ & $2.48 \pm 0.22$ \\
\hline Calcium $\left(\mathrm{mg} \mathrm{Ca} \mathrm{L}^{-1}\right)$ & $6.34 \pm 0.94$ & $5.44 \pm 1.78$ & $4.11 \pm 0.96$ & $23.21 \pm 2.46$ & $38.02 \pm 3.66$ \\
\hline Total phosphorus (mg P L ${ }^{-1}$ ) & $0.11 \pm 0.02$ & $0.09 \pm 0.02$ & $0.08 \pm 0.02$ & $0.10 \pm 0.02$ & $0.09 \pm 0.02$ \\
\hline $\begin{array}{l}\text { Dissolved aluminum } \\
\left(\mathrm{mg} \mathrm{Al}{ }^{3+} \mathrm{L}^{-1}\right)\end{array}$ & $0.038 \pm 0.003$ & $0.015 \pm 0.004$ & $0.016 \pm 0.002$ & $0.008 \pm 0.004$ & $0.007 \pm 0.007$ \\
\hline $\mathrm{TOC}\left(\mathrm{mg} \mathrm{C} \mathrm{L}^{-1}\right)$ & $27.25 \pm 1.23$ & $19.67 \pm 2.19$ & $15.75 \pm 1.58$ & $9.77 \pm 1.59$ & $8.86 \pm 1.01$ \\
\hline
\end{tabular}



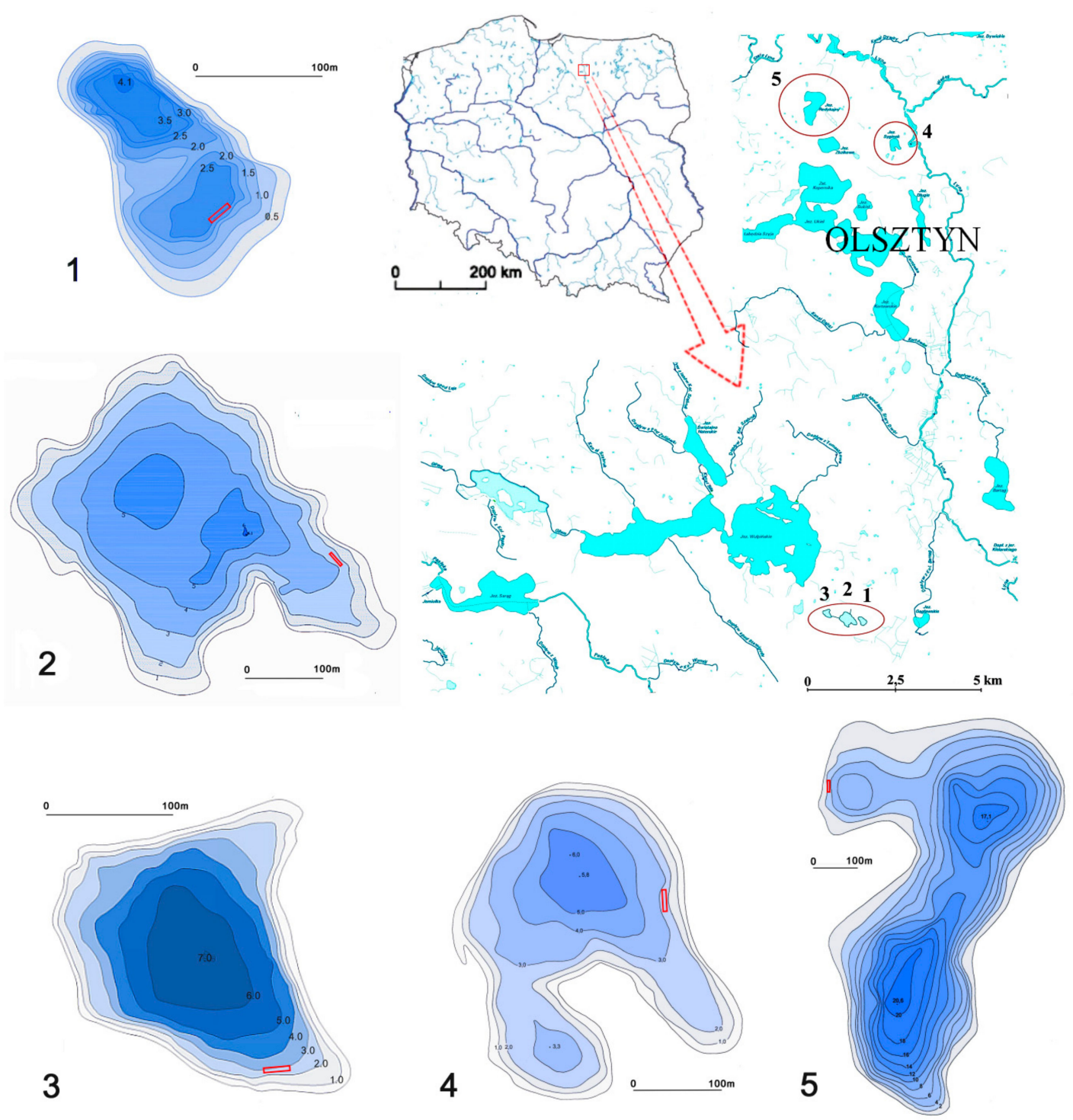

Figure 1. Location and bathymetric plans of examined lakes (1-Kluka Mała, 2-Kluka Duża, 3-Zbiornik Zachodni, 4-Podkówka, 5-Redykajny). Map sources: Czarnecka [20], Lossow et al. [21], Kowalczuk [22], Gut [23], Rusiecki [24]. Red rectangles-location of mesocosms.

\subsection{Research Plan}

The selected lakes made an ideal model system due to their similar level of anthropogenic pressure and trophic status but different water buffering capabilities. This allowed us to investigate the variability of ecosystem responses to external factors, which in our case was the addition of a coagulant immobilizing phosphorus, the main element responsible for the eutrophication of these lakes [4].

Four mesocosm experiments were installed in each lake and designed to ensure natural, free exchange of ions between the bottom sediment and water. The experimental enclosures were made as cylindrical containers, $3 \mathrm{~m}$ in diameter and $3 \mathrm{~m}$ in height. The round cross-section enabled us to achieve the best ratio of the total lateral wall surface to the volume of water inside the container. The cylindrical shape of the experimental containers was also helpful in mixing water during an application of the coagulant, and limited the formation of chemical gradients of water during the experiment. The mesocosm frame was made of steel rings stretched on vertical poles. The side walls were made of transparent polyester. The enclosures were bottomless. The lower ring of each mesocosm was additionally fitted with stabilisation plates, placed $15 \mathrm{~cm}$ above the edge of the lateral walls. 
This made the enclosures sealed at the lake bed (by submerging the edges slightly into the lake bed) and prevented the containers from excessively settling down into the lake bed. All elements of the structure were placed outside the container's walls to ensure that any possible corrosion of these elements had no effect on the chemism of lake water within it. The enclosures were placed in a row, parallel to the lake shoreline. The distance between them was about 1.0 to 1.5 times the height of the lateral walls, so that individual containers did not cast shadow onto one another. Each set of mesocosms was situated within the area of uniform sediments, and exposed to the same atmospheric conditions. Details of the shape and structure of enclosures are illustrated in Figure 2.

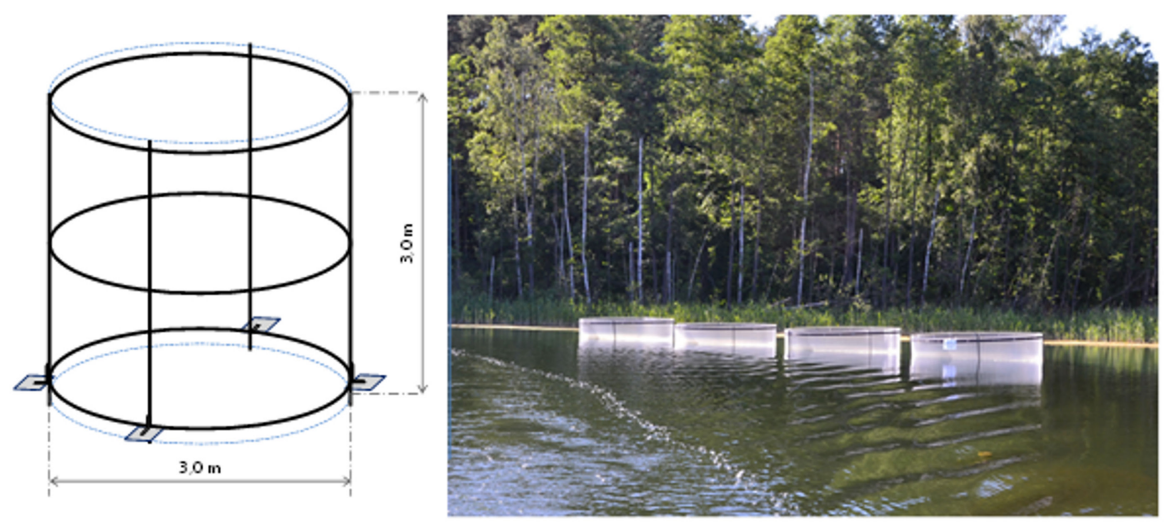

Figure 2. Experimental enclosures—dimensions and arrangement in the field. Photograph by Michał Łopata.

Injection of the coagulant into the enclosures was carried out in a way that resembled the application of preparations on a technical scale. Typically, application is conducted from boats equipped with systems of perforated pipes, through which preparations are added in droplets into surface layers of water [1,7]. In our experiment, the coagulant was dripped over the surface of water from a container fitted with a spout closed with a perforated cap, held in a telescopic arm. After the application, the surface layer of water was gently mixed. This meant that the coagulant was uniformly spread in each enclosure. Samples of water for analysis were collected at approximately monthly intervals, from a depth of $1 \mathrm{~m}$ under the water surface.

The theoretical dose of the coagulant required for the immobilization of excess phosphorus in each lake was determined based on the phosphorus content in the water column and in the bottom sediment, according to Rydin and Welch's [25] findings. The cited research indicates that estimation of a dose of aluminium should rely on the pool of mobile phosphorus in the bottom sediments (labile fractions and phosphorus bound to components sensitive to changes in the redox potential). It was determined that a dose of aluminium immobilizing phosphorus should be applied in an Al:P weight ratio equal to 100:1, converted per pool of phosphorus contained in the dry matter of the surface layer of the bottom sediments. The doses of aluminium calculated as explained above were slightly modified by adding a relatively small (9-12\%) amount needed to precipitate phosphorus from the water column. This additional quantity was calculated according to the average phosphorus abundance in each lake, taking into account the concentrations identified in the surface, bottom, and near-bottom water $(10 \mathrm{~cm}$ above the sediments). In line with the authors' earlier experiments [26], it was assumed that polyaluminium chloride should be applied in an Al:P weight ratio of 10:1. Thus, the final calculated doses of the coagulant were all approximately $11 \mathrm{~g} \mathrm{Al} \mathrm{m}^{-3}\left(29 \mathrm{~g} \mathrm{Al} \mathrm{m}^{-2}\right.$ lake bottom). These doses are close to the ones applied in technical scale protocols, where they range from 4 to $138 \mathrm{~g} \mathrm{Al} \mathrm{m}^{-2}$ lake bottom, with an average of $32 \mathrm{~g} \mathrm{Al} \mathrm{m}^{-2}$ (Welch, after [13]). In our study, polyaluminium chloride (PAC) was used in the form of a solution ( $9 \% \mathrm{Al}$ liquid solution, proper weight $\left.1.36 \mathrm{~kg} / \mathrm{L}^{-1}\right)$. The Al doses calculated above corresponded to the use of $92 \pm 8 \mu \mathrm{L} \mathrm{L}^{-1}$ of the technical preparation. For practical reclamation of a lake, the necessary amount of a coagulant is usually divided into sub-doses according to a specific restoration project. Most such projects are conducted for two to 
three years, and include several coagulant applications (one-two per year). The experiments were conducted over two consecutive years to simulate actual lake restoration projects.

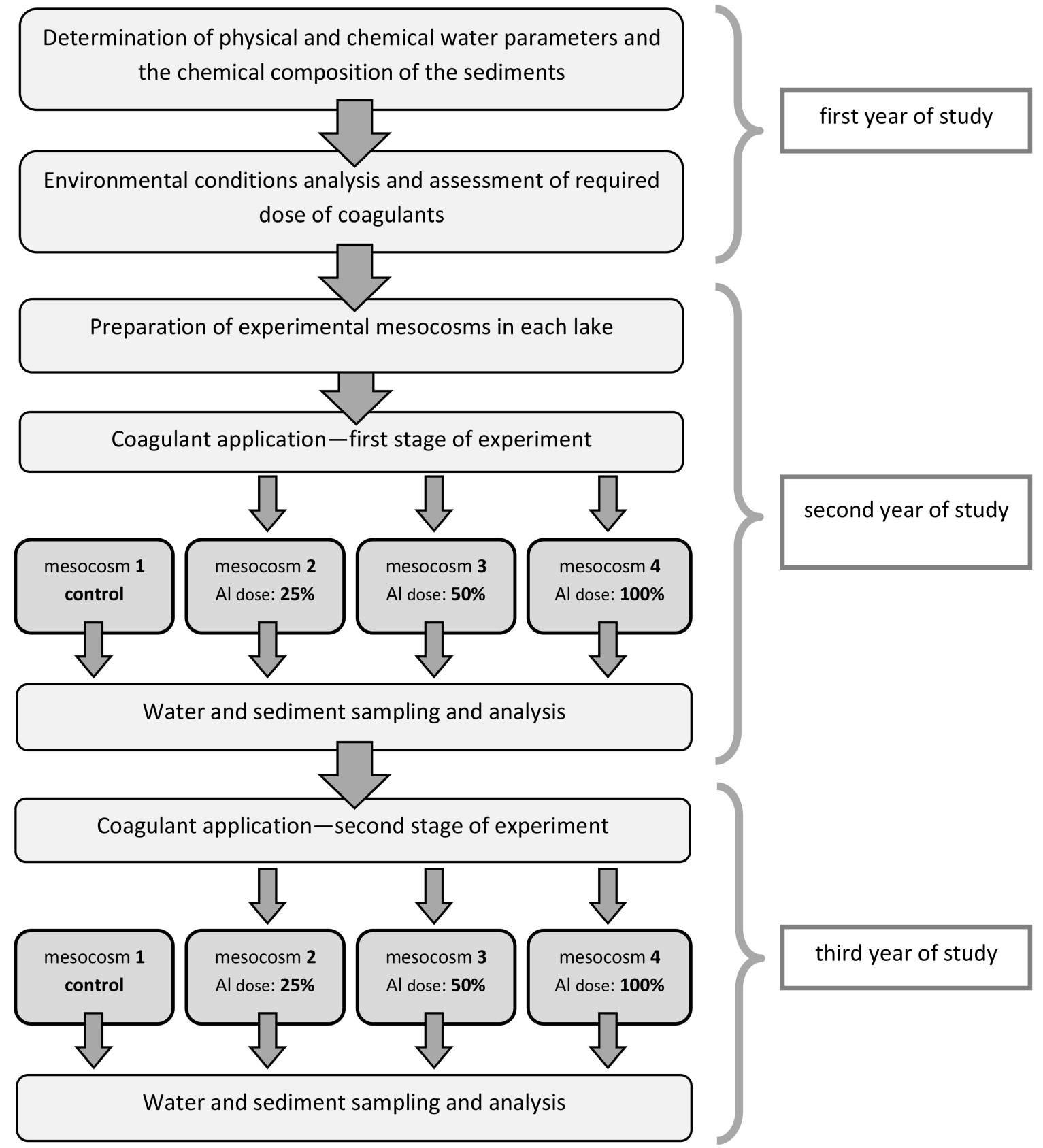

Figure 3. Flowchart describing the research schedule.

In each lake, the coagulant was introduced to mesocosms in an amount of $100 \%, 50 \%$, and $25 \%$ of the required total dose (Figure 3). This corresponds to a single application in a project consisting of one, two, and four stages. Such an experimental design allowed us to observe the response of an ecosystem to different doses of aluminum. A dose of the coagulant was repeated at the beginning of the research cycle in the subsequent year of the experiment. Thus, the amount of coagulant introduced into individual lakes finally reached double, whole, and half of the total dose. The control treatment consisted of samples collected from enclosures placed in each lake in order to observe the interaction between the lake's water and bottom sediments not subjected to the impact of aluminum in the environment. 


\subsection{Sampling and Analysis Procedures}

Samples of water were taken four to five times during the growing season (April-October) of the year preceding the project (preliminary investigations) and of the next two years during the experimental period. In the whole research, sampling was done in the surface water layer, near-bottom water, and by taking cores of sediments $20 \mathrm{~cm}$ in thickness, divided into four $5 \mathrm{~cm}$-thick layers. The interstitial water obtained from these sediment samples was also tested. The monitoring parameters of surface water presented in this paper included total phosphorus (TP), alkalinity (Alk), and reaction (pH), all analyzed according to the Standard Methods [27]. Dissolved aluminum was determined after filtration of samples through $0.45 \mu \mathrm{m}$ glass-fibre filters using the eriochrome cyanine $\mathrm{R}$ photometric technique. Water reaction $(\mathrm{pH})$ was measured in situ with an CX-401 pH-meter (Elmetron RP, Zabrze, Poland).

Statistical analysis included comparative statistics and testing the significance of differences between the selected parameters in the matched-pairs system. The normality of data sets was checked with the Shapiro-Wilk test, and when the result was positive the t-test was performed, or else, when the result was negative, the Wilcoxon matched-pairs signed-ranks test was carried out. All statistical analyses were conducted using Statistica 12.0 software (StatSoft, Inc. Tulsa, OK, USA).

\section{Results and Discussion}

\subsection{Environmental Characteristics of the Lakes-Preliminary Results}

The investigated lakes are a group of water bodies with various physical and chemical parameters, potentially affecting the efficiency of water treatment using acidic aluminum coagulants. The range of variation in basic water quality indicators is presented in Table 1.

All the tested lakes were characterized by a relatively high content of organic matter. In terms of the total organic carbon, the amount of organic compounds ranged from about 10 to $25-30 \mathrm{mg} \mathrm{TOC} \mathrm{L}^{-1}$.

Three lakes were characterized by a distinctly higher organic matter content: Kluka Mała (25-30 mg TOC L ${ }^{-1}$ ), Kluka Duża (about $20 \mathrm{mg} \mathrm{TOC} \mathrm{L}^{-1}$ ), and Zbiornik Zachodni (16-18 mg TOC L ${ }^{-1}$ on average). Simultaneously, they had a relatively high content of humic substances in water $(87 \%$, $40 \%$, and $59 \%$ of the total organic carbon on average, respectively). The specific chemical composition of water was caused by the conditions in the drainage basin. These lakes, located close to one another, are surrounded mostly by forests and peat bogs. This makes the export of mineral nutrients (such as calcium and magnesium) from the catchment to the lake water much more difficult, and in consequence the water of these lakes has low alkalinity and slightly acidic $\mathrm{pH}$. The other two lakes were characterized by a much smaller amount of humic substances $\left(1-3 \mathrm{mg} \mathrm{L}^{-1}\right)$, with the total amount of organic compounds oscillating around $10 \mathrm{mg} \mathrm{TOC} \mathrm{L}^{-1}$ [28].

\subsection{Changes in Water Chemistry after the Application of Polyaluminium Chloride—in Situ Experiments}

The main aim of the chemical lake restoration methods is to remove excess phosphorus from the water. The use of hydrolyzable coagulants makes it possible to divide the phosphorus precipitation mechanisms into into three groups, according to the following reactions:

- Phosphate binds to hardly soluble aluminum phosphate and precipitates;

- Positively charged aluminum hydroxide polymers react with $\mathrm{PO}_{4}{ }^{3-}$;

- Suspended organic and mineral matter containing insoluble P precipitates via coagulation and flocculation.

According to Klapper [1], the latter process may be the most important one in the purification of natural waters. Lakes included in this experiment were rich in organic matter, in the form of both bio- and abioseston, as well as dissolved fractions. Thus, the effect of reducing the phosphorus concentration was achieved via the co-occurrence of the above processes. The highest efficiency of the removal of phosphorus from the water column was obtained in the lakes with the highest capacity buffer, i.e., Podkówka and Redykajny (Figure 4). This efficiency, regardless of the dose of 
the coagulant, was always higher by $50 \%$ in comparison with the phosphorus content in the control mesocosms. Similar relationships for lake water with similar but slightly higher alkalinity were found by Gawrońska et al. [26]. It is worth noting that the efficiency of the treatment for both of the mentioned lakes increased with a higher dose of the coagulant, up to the maximum value for Lake Redykajny. However, the increase in coagulant efficiency was only evident between the use of 0.5 and 1.0 of the assumed dose. Doubling the required dose no longer resulted in a marked improvement in coagulation efficiency. The phosphorus reduction level for doses of 0.5, 1.0, and 2.0 for lakes Podkówka and Redykajny was $51 \%, 69 \%, 72 \%$ and $55 \%, 73 \%, 81 \%$, respectively (Table 2). For these lakes, the method used to calculate the required coagulant dose proved to be useful. Obtaining about $70 \%$ reduction of water content in this main biogenic element should be considered satisfactory. Both Podkówka and Redykajny are characterized by a relatively high level of primary production, resulting in the depletion of mineral forms of phosphorus assimilated by phytoplankton. Thus, they are an example of lakes where the percentage reduction of the trophic state using polyaluminium chloride is directly related to the coagulation within the seston and clarification of the water column by co-precipitation of biosestion during the formation and sedimentation of aluminum hydroxide flocs. Similar results, although with a lower efficiency of the tested treatment, were observed in the mesocosms in Kluka Duża Lake, distinguished by a relatively high level of autotrophic organic matter [28].

The precipitation of phosphorus from water was found to be demonstrably less efficient in two lakes: Kluka Mała and Zbiornik Zachodni (Table 2). These lakes are characterized by the lowest $\mathrm{pH}$ and the greatest richness in humic substances; in fact both, lakes are dystrophic ones. After the addition of coagulant to the mesocosms in these two lakes, dissolved aluminium compounds were present in the water column. High acidification in these mesocosms resulted in decreasing phosphorus binding efficiency, as the coagulant dose was increased beyond the theoretical demand, previously calculated as $11 \mathrm{~g} \mathrm{Al} \mathrm{m}^{-3}$.

Although aluminum is quantitatively the third most abundant component of the lithosphere-after oxygen and silicon [19] — and hence, a natural constituent of lake sediments, this element can be significantly toxic to hydrobionts in the aquatic environment. It is widely known that aluminum remaining in water in the dissolved form has a negative impact on living organisms [29-32]. The solubility of aluminum depends on water $\mathrm{pH}$ and is lowest in the $\mathrm{pH}$ range of 5-9. According to many authors, this element practically does not occur in the dissolved form at $\mathrm{pH} \mathrm{6-8} \mathrm{[33-35].} \mathrm{Thus,}$ the key factor to ensuring ecological safety is to maintain the $\mathrm{pH}$ of water close to neutral.

The range of changes in water $\mathrm{pH}$ and dissolved aluminum concentrations is presented in Table 2. The results clearly indicate the exhaustion of the buffer capacity and the acidification of the environment after the application of the coagulant in three lakes: Kluka Mała, Kluka Duża, and Zbiornik Zachodni, which corresponds to their level of alkalinity. However, in Kluka Duża Lake this effect occurred only after the application of the excessive (doubled) doses of the coagulant. The coagulant used in lower doses allowed the $\mathrm{pH}$ level to remain close to 6.0, which enabled efficient precipitation of aluminum, especially when the standard dose of the coagulant was applied. Considering the need for environmental safety, it would be more beneficial to keep the water $\mathrm{pH}$ closer to 7.0. In this case, the preferred treatment may include adding a substance capable of improving the water buffer capacity [31]. The results of our research [36] show that even a low dose of calcium carbonate $\left(0.1 \mathrm{~g} \mathrm{~L}^{-1}\right)$ and the improvement of the natural buffering properties of water by about $1 \mathrm{meq} \mathrm{L}^{-1}$ significantly increases the resistance of an ecosystem against an acidic coagulant, and the residual aluminum load declines to environmentally acceptable values $\left(<0.05 \mathrm{mg} \mathrm{L}^{-1}\right)$. 

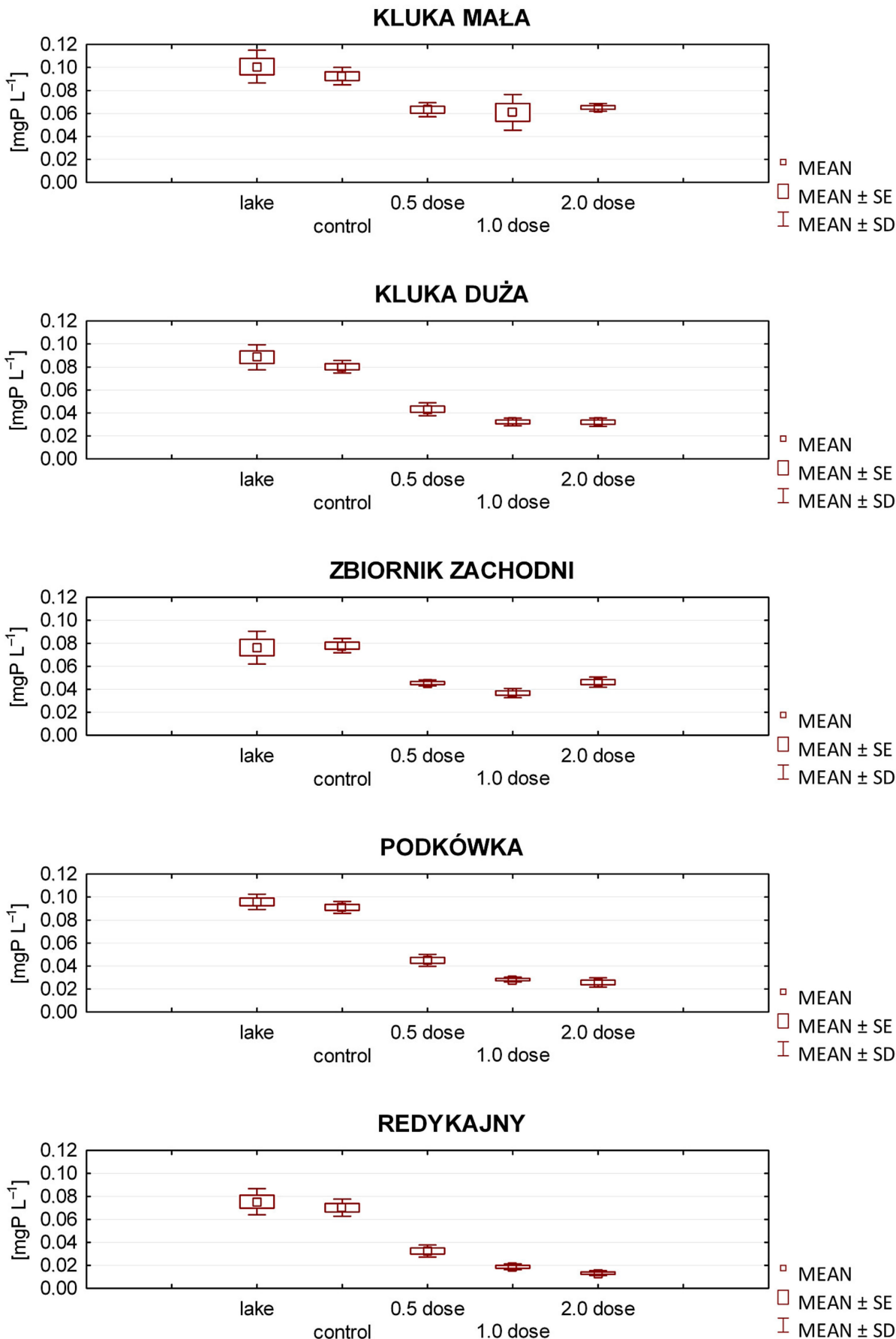

Figure 4. Changes in the total phosphorus content in the examined lakes. Data from experimental enclosures represent values achieved in the growing season after the application of the whole amount of coagulant. 
Table 2. The range of variability of water parameters in lakes subjected to experiments (examinations carried out in the growing season of the last year of the study, after application of the whole amount of coagulant, ctrl—control mesocosms, ${ }^{*}$ - statistically significant decrease in phosphorus concentration at $p<0.05$, compared to ctrl).

\begin{tabular}{|c|c|c|c|c|c|c|c|c|c|c|c|}
\hline \multirow[t]{2}{*}{ Parameter } & \multirow[t]{2}{*}{ Unit } & \multicolumn{5}{|c|}{$\begin{array}{c}\text { Kluka Mała } \\
\text { Dose Multiplicity }\end{array}$} & \multicolumn{5}{|c|}{$\begin{array}{c}\text { Kluka Duża } \\
\text { Dose Multiplicity }\end{array}$} \\
\hline & & Lake & Ctrl & 0.5 & 1.0 & 2.0 & Lake & Ctrl & 0.5 & 1.0 & 2.0 \\
\hline \multirow{3}{*}{$\begin{array}{c}\text { total phosphorus } \\
\mathrm{pH} \text { value } \\
\text { dissolved } \\
\text { aluminum }\end{array}$} & $\%$ reduction & - & - & $32^{*}$ & $34^{*}$ & $29^{*}$ & - & - & $47^{*}$ & $60^{*}$ & $60^{*}$ \\
\hline & Mean $\pm \mathrm{SD}(\mathrm{pH})$ & $6.31 \pm 0.35$ & $6.27 \pm 0.21$ & $5.72 \pm 0.61$ & $5.34 \pm 0.38$ & $4.55 \pm 0.56$ & $7.22 \pm 1.01$ & $7.25 \pm 0.95$ & $6.13 \pm 0.16$ & $5.96 \pm 0.48$ & $4.63 \pm 0.74$ \\
\hline & $\begin{array}{c}\text { Mean } \pm \text { SD } \\
\left(\mathrm{mgAl}^{3+} \mathrm{L}^{-1}\right)\end{array}$ & $0.035 \pm 0.006$ & $0.036 \pm 0.003$ & $0.373 \pm 0.196$ & $0.232 \pm 0.212$ & $2.775 \pm 0.491$ & $0.018 \pm 0.003$ & $0.024 \pm 0.005$ & $0.072 \pm 0.026$ & $0.050 \pm 0.011$ & $0.589 \pm 0.115$ \\
\hline \multirow[t]{2}{*}{ Parameter } & \multirow[t]{2}{*}{ Unit } & \multicolumn{5}{|c|}{$\begin{array}{l}\text { Zbiornik Zachodni } \\
\text { Dose Multiplicity }\end{array}$} & \multicolumn{5}{|c|}{$\begin{array}{c}\text { Podkówka } \\
\text { Dose Multiplicity }\end{array}$} \\
\hline & & Lake & Ctrl & 0.5 & 1.0 & 2.0 & Lake & Ctrl & 0.5 & 1.0 & 2.0 \\
\hline \multirow{3}{*}{$\begin{array}{c}\text { total phosphorus } \\
\mathrm{pH} \text { value } \\
\text { dissolved } \\
\text { aluminum }\end{array}$} & \multirow{3}{*}{$\begin{array}{c}\% \text { reduction } \\
\text { Mean } \pm \mathrm{SD}(\mathrm{pH}) \\
\text { Mean } \pm \mathrm{SD} \\
\left(\mathrm{mgAl}^{3+} \mathrm{L}^{-1}\right)\end{array}$} & - & - & $42^{*}$ & $53^{*}$ & $41^{*}$ & - & - & $51^{*}$ & $69^{*}$ & $72^{*}$ \\
\hline & & $6.46 \pm 0.18$ & $6.43 \pm 0.16$ & $4.77 \pm 0.27$ & $4.52 \pm 0.29$ & $3.75 \pm 0.35$ & $7.94 \pm 0.32$ & $8.61 \pm 0.17$ & $8.40 \pm 0.15$ & $7.99 \pm 0.10$ & $7.14 \pm 0.82$ \\
\hline & & $0.018 \pm 0.003$ & $0.019 \pm 0.004$ & $0.128 \pm 0.032$ & $1.189 \pm 0.940$ & $4.669 \pm 1.324$ & $0.014 \pm 0.004$ & $0.016 \pm 0.007$ & $0.072 \pm 0.030$ & $0.029 \pm 0.009$ & $0.050 \pm 0.036$ \\
\hline \multirow[t]{2}{*}{ Parameter } & \multirow[t]{2}{*}{ Unit } & \multicolumn{10}{|c|}{$\begin{array}{c}\text { Redykajny } \\
\text { Dose Multiplicity }\end{array}$} \\
\hline & & \multicolumn{2}{|c|}{ Lake } & \multicolumn{2}{|c|}{ Ctrl } & \multicolumn{2}{|c|}{0.5} & \multicolumn{2}{|c|}{1.0} & \multicolumn{2}{|c|}{2.0} \\
\hline \multirow{3}{*}{$\begin{array}{l}\text { total phosphorus } \\
\mathrm{pH} \text { value } \\
\text { dissolved } \\
\text { aluminum }\end{array}$} & $\%$ reduction & & & \multicolumn{2}{|c|}{$55^{*}$} & \multicolumn{2}{|c|}{$73^{*}$} & \\
\hline & Mean $\pm \mathrm{SD}(\mathrm{pH})$ & \multirow{2}{*}{\multicolumn{2}{|c|}{$\begin{array}{c}8.29 \pm 0.24 \\
0.012 \pm 0.006\end{array}$}} & \multicolumn{2}{|c|}{$8.73 \pm 0.21$} & \multicolumn{2}{|c|}{$8.38 \pm 0.16$} & \multicolumn{2}{|c|}{$8.19 \pm 0.10$} & \multicolumn{2}{|c|}{$8.00 \pm 0.46$} \\
\hline & $\begin{array}{c}\text { Mean } \pm \text { SD } \\
\left(\mathrm{mgAl}^{3+} \mathrm{L}^{-1}\right)\end{array}$ & & & 0.014 & \pm 0.007 & $0.079=$ & $=0.050$ & 0.024 & 0.008 & 0.021 & \pm 0.017 \\
\hline
\end{tabular}


It can be seen that the potential risk of dissolved aluminum forms arises from acidification as well as excessive water alkalinisation, which is characteristic for lakes with low calcium content. Photosynthetic activity of primary producers in lakes with low alkalinity can easily lead to an increase in water $\mathrm{pH}$, up to $\mathrm{pH} 8.5$ and above [19]. The reason for this is the depletion of $\mathrm{CO}_{2}$ in water by autotrophic organisms and further uptake of this compound from carbonates and bicarbonates, leading to an increase in the amount of $\mathrm{OH}^{-}$ions in the water. In our research, the periodic occurrence of such high pH in the three most eutrophic lakes (Kluka Duża, Podkówka, and Redykajny) was found. In Podkówka Lake and Redykajny Lake, pH levels $>8.5$ were observed even in the mesocosms subjected to the application of the acid coagulant (used in the lowest dose). Earlier studies on polyaluminium chloride indicate that precipitation of insoluble forms of aluminium after application decreases sharply when the $\mathrm{pH}$ changes from 8.3 to 8.9 [37]. According to these findings, it can be assumed that the appearance of slightly elevated $\mathrm{Al}^{3+}$ ion concentrations in these mesocosms $\left(0.07-0.08 \mathrm{mg} \mathrm{Al} \mathrm{L}^{-1}\right)$ was associated with the negative impact of excessively high $\mathrm{pH}$ on the effectiveness of the PAC flocculation process. On the other hand, the water $\mathrm{pH}$ at higher doses of the acidic coagulant remained lower during the application, and throughout the monitoring period was closer to optimal, which facilitated the sedimentation of aluminum hydroxide flocs. This is consistent with the authors- observations made during the implementation of full-scale projects, where polyaluminum chloride was applied [15,38]. Considering the environmental impact of phosphorus inactivation (decreasing of excessive $\mathrm{pH}$ in the water column), our results indicate that the application of one higher coagulant dose may be preferable to application of several smaller doses. The results also prove how important it is to adjust the application dose of the coagulant in order to achieve optimum conditions for the precipitation of aluminum to a particulate form, which is no longer toxic to hydrobionts.

In three lakes, Kluka Duża, Podkówka, and Redykajny, after the application of the theoretically required standard dose of the coagulant, the mean amount of dissolved aluminum during the research period did not exceed $50 \mu \mathrm{g} \mathrm{L} \mathrm{L}^{-1}$, which is considered safe for the environment [30,31]. In connection with the satisfactory efficiency of phosphorus removal from lake water, our examinations justify the use of phosphorus inactivation for lowering the trophic state in lakes with similar water chemistry.

The results achieved during the experiment suggested the presence of a lock-in effect. We observed some minor deviations in physicochemical conditions in the water sampled at the experimental sites (control mesocosms), in comparison with the open water area. It was shown that for both tested parameters-aluminum and phosphorus concentrations-the effect was inversely proportional to the level of autotrophy in a given lake. Similar relationships were also detected for the organic matter indicators [28]. The most notable differences in the phosphorus concentration between lake and control mesocosm were found in lakes Kluka Duża, Podkówka, and Redykajny ( $9 \%, 5 \%$, and $7 \%$ on average, respectively). Even bigger differences were noted regarding aluminum compounds. The $\mathrm{Al}^{3+}$ amount in the water inside the control mesocoms exceeded concentrations in the open water of lakes by about $31 \%, 18 \%$, and $11 \%$, respectively, although it concerned the concentrations within quite a low range (below $0.04 \mathrm{mg} \mathrm{L}^{-1}$ ). The reason for this could be the impact of biotic elements of the experimental sets, namely the most intensive development of periphytic organisms on the walls of the enclosures in these lakes. Populations of periphyton, especially algae, are capable of effectively assimilating nutrients from the water [39] and distorting the carbonate water system during the autotrophic processes [40], which results in an increasing $\mathrm{pH}$. Indirectly, elevation of the $\mathrm{pH}$ (periodically up to 8.7-8.9 $\mathrm{pH}$ ) could determine the release of aluminum from the ecosystem's abiotic components inside the mesocosm. The effect of periphyton on water properties in mesocosms experiments, previously described in the literature [41,42], confirms the need for taking into consideration the metabolic processes of hydrobionts during in situ experiments dealing with the improvement of technical methods of lake restoration.

\section{Conclusions}

The high success rate in phosphorus removal from natural waters by aluminium coagulants makes these preparations a very attractive choice in lake restoration. However, aluminium in water 
of an inadequate $\mathrm{pH}(<6$ and $>8)$ can occur in the soluble form and, as such, can be toxic to water organisms. This restricts its application in lakes that have weak buffer capacities, vulnerable to acidification. In this study, conducted in mesocosms, an analysis was made to explore the effects of using different doses of an aluminium coagulant in five lakes with alkalinity below 2.5 meq $\mathrm{L}^{-1}$. It was demonstrated that the phosphorus precipitation rate can differ greatly. At a dose needed to be supplied in order to inactivate phosphorus on a technical scale (around $11 \mathrm{~g} \mathrm{~L}^{-1}$ ), the achieved phosphorus reduction equaled $34 \%$ to $73 \%$. The efficiency of phosphorus binding was proportional to the buffer capacity of water, but it was not a simple, linear relationship. The most successful application of the coagulant in terms of phosphorus precipitation was detected in two lakes with the highest alkalinity: $1.5-2.5$ meq L $^{-1}$ (phosphorus reduction $69-73 \%$, negligible amounts of aluminium left in water after the treatment $<0.05 \mathrm{mg} \mathrm{L}^{-1}$ ). Three of the five tested lakes that were most susceptible to acidification, despite having a similar alkalinity level $\left(0.5-0.7 \mathrm{meq} \mathrm{L}^{-1}\right)$, presented different responses to the application of polyaluminium chloride. In two lakes, with the most advanced dystrophy, the $\mathrm{pH}$ was found to have been distinctly lowered. This effect was accompanied by a high load of water with dissolved aluminium (even more than $1 \mathrm{mg} \mathrm{L}^{-1}$ ). In the last of the analyzed lakes, a similar dose of the coagulant did not cause such negative changes, and the amount of dissolved aluminium after the treatment remained at an ecologically acceptable level of $0.05 \mathrm{mg} \mathrm{L}^{-1}$. The results suggest that phosphorus immobilization treatments should be designed individually for each soft-water lake. In the case of lakes with evident dystrophic features, associated with a naturally high content of organic matter and low buffer capacity, one should always consider whether the proposed method will bring more benefits than environmental losses. Thus, lake restoration requires paying attention to the natural level of organic matter present and the effect of different application strategies on both hydrochemistry and hydrobiology. In lakes with alkalinity $<1.5 \mathrm{meq}^{-1}$, it is recommended to always conduct in situ pilot studies. A dose of a coagulant estimated on the basis of methods implemented in well-buffered lakes could be too high. It is also advisable to analyze the response of a lake to the application of coagulants in subdoses, as such a dosage does not always ensure that the obtained level of dissolved aluminium forms in lake would be ecologically safe.

Author Contributions: Conceptualization, M.Ł. and R.A.; Methodology, M.Ł. and R.A.; Formal analysis, M.Ł. and K.P.; Investigation, M.Ł., R.A. and J.G.; Writing—original draft preparation, M.Ł. and J.G.; Writing-review and editing, M.Ł. and R.T; Visualization, M.Ł. and K.P.; Supervision, R.T.

Funding: The study was funded by the Polish National Science Centre according to decision number DEC-2012/05/B/ST10/02178. In addition, this project was financially supported by Minister Of Science and Higher Education in the range of the program entitled „Regional Initiative of Excellence” for the years 2019-2022, project No. 010/RID/2018/19, amount funding 12.000.000 PLN".

Acknowledgments: The authors wish to thank Konrad Rusiecki, Kamil Pstragowski and Radosław Sternicki for field work assistance. We are also grateful to Grzegorz Wiśniewski, for his valuable assistance in the implementation of this study.

Conflicts of Interest: The authors declare no conflict of interest.

\section{References}

1. Klapper, H. Control of Eutrophication in Inland Waters; Ellis Horwood Ltd Publishing: New York, NY, USA, 1991; pp. 116-266.

2. Søndergaard, M.; Jeppesen, E.; Jensen, J.P.; Lauridsen, T. Lake restoration in Denmark. Lake Res. Res. Manag. 2000, 5, 151-159. [CrossRef]

3. Lu, S.J.; Si, J.H.; Hou, C.Y.; Li, Y.S.; Wang, M.M.; Yan, X.X.; Xie, M.; Sun, J.X.; Chen, B.J.; Li, S.S. Spatiotemporal distribution of nitrogen and phosphorus in alpine lakes in the Sanjiangyuan Region of the Tibetan Plateau. Water Sci. Technol. 2017, 76, 396-412. [CrossRef] [PubMed]

4. Kajak, Z. Hydrobiology-limnology. Freshwater Ecosystems; PWN Publishing: Warsaw, Poland, 2001; pp. $139-187$.

5. Søndergaard, M.; Jensen, J.P.; Jeppesen, E. Role of sediment and internal loading of phosphorus in shallow lakes. Hydrobiologia 2003, 506, 135-145. [CrossRef] 
6. Water Framework Directive. Directive 2000/60/EC of the European Parliament and of the Council of 23 October 2000 establishing a framework for Community action in the field of water policy. Off. J. Eur. Communities 2000, 22, 2000.

7. Spears, B.M.; Dudley, B.; Reitzel, K.; Rydin, E. Geoengineering in lakes-A call for consensus. Environ. Sci. Technol. 2013, 47, 3953-3954. [CrossRef] [PubMed]

8. OECD. OECD Environmental Performance Reviews: Poland 2015; OECD Publishing: Paris, France, 2015.

9. Lee, L.Y.; Wang, B.; Guo, H.; Hu, J.Y.; Ong, S.L. Aluminum-based water treatment residue reuse for phosphorus removal. Water 2015, 7, 1480-1496. [CrossRef]

10. Ojo, P.; Ifelebuegu, A.O. Effect of aluminium salt dosing on activated sludge settleability indicators: A new settleability model development. Water 2019, 11, 179. [CrossRef]

11. Łopata, M.; Gawrońska, H. Effectiveness of the polymictic Lake Głęboczek in Tuchola restoration by the phosphorus inactivation method. Pol. J. Nat. Sci. 2006, 21, 859-870.

12. Immers, A.K.; Bakker, E.S.; Van Donk, E.; Ter Heerdt, G.N.J.; Geurts, J.J.M.; Declerck, S.A.J. Fighting internal phosphorus loading: An evaluation of the large scale application of gradual Fe-addition to a shallow peat lake. Ecol. Eng. 2015, 83, 78-89. [CrossRef]

13. Jensen, H.S.; Reitzel, K.; Egemose, S. Evaluation of aluminum treatment efficiency on water quality and internal phosphorus cycling in six Danish lakes. Hydrobiologia 2015, 751, 189-199. [CrossRef]

14. Jančula, D.; Maršálek, B. Seven years from the first application of polyaluminium chloride in the Czech Republic-effects on phytoplankton communities in three water bodies. Chem. Ecol. 2012, 28, 535-544. [CrossRef]

15. Grochowska, J.; Brzozowska, R.; Łopata, M. Durability of changes in phosphorus compounds in water of an urban lake after application of two reclamation methods. Water Sci. Technol. 2013, 68, 234-239. [CrossRef] [PubMed]

16. Grochowska, J.; Augustyniak, R.; Łopata, M.; Parszuto, K.; Tandyrak, R.; Płachta, A. From saprotrophic to clear water status: The restoration path of a degraded urban lake. Water Air Soil Pollut. 2019, 230, 94. [CrossRef]

17. Dunalska, J.; Ciecierska, H.; Napiórkowska-Krzebietke, A.; Ruszczyńska, J.; Sieńska, J.; Szymański, D. Lakes of Olsztyn: The Most Beautiful Gift of Nature: Trophic State and Ecology; Mantis Publishing: Olsztyn, Poland, 2017; pp. 18-32.

18. Jańczak, J. The Atlas of Polish Lakes; The Institute of Meteorology and Water Management-National Research Institute (IMGW-PIB)/Bogucki, S.C.: Poznań, Poland, 1999; pp. 13-85.

19. Dojlido, J.R. Chemistry of Surface Waters; Economy and Environment: Białystok, Poland, 1995; pp. 65-188.

20. Czarnecka, H. The Atlas of Hydrographic Division of Poland; The Institute of Meteorology and Water Management: Warsaw, Poland, 2005.

21. Lossow, K.; Gawrońska, H.; Mientki, C.; Łopata, M.; Wiśniewski, G. Lakes of Olsztyn-Trophic Status, Threats; SPW Edycja: Olsztyn, Poland, 2005; pp. 1-164.

22. Kowalczuk, P. Morphometry and Bathymetry of Lake Kluka Mała. Bachelor's Thesis, University of Warmia and Mazury in Olsztyn, Olsztyn, Poland, 2015.

23. Gut, M. Morphometry and Bathymetry of Lake Kluka Duża. Bachelor's Thesis, University of Warmia and Mazury in Olsztyn, Olsztyn, Poland, 2015.

24. Rusiecki, K. Bathymetric Map and Morphometric Characteristics of Lake "Zbiornik Zachodni" (Olsztyńskie Lake District). Bachelor's Thesis, University of Warmia and Mazury in Olsztyn, Olsztyn, Poland, 2015.

25. Rydin, E.; Welch, E.B. Aluminum dose required to inactivate phosphate in lake sediments. Water Res. 1998, 32, 2969-2976. [CrossRef]

26. Gawrońska, H.; Brzozowska, R.; Grochowska, J.; Lossow, K. Effectiveness of PAX and PIX coagulants in phosphorus reduction in a lake-laboratory experiments. Limnol. Rev. 2001, 1, 73-82.

27. American Public Health Association (APHA). Standard Methods for the Examination of Water and Wastewater, 21st ed.; American Water Works Association/Water Pollution Control Federation: Washington, DC, USA, 2005.

28. Łopata, M.; Wiśniewski, G.; Augustyniak, R. Changes of the organic matter content in the water of lakes with low alkalinity occurring under the influence of the use aluminum salts. In Hydrology and Water Resources, Proceedings of the 16-th International Multidisciplinary Scientific GeoConference SGEM, Albena, Bulgaria 28 June-6 July 2016; STEF92 Technology Ltd.: Sofia, Bulgaria, 2016. 
29. Poléo, A.B.S. Aluminium polymerization-a mechanism of acute toxicity of aqueous aluminium to fish. Aquat. Toxicol. 1995, 31, 347-356. [CrossRef]

30. Wauer, G.; Heckemann, H.J.; Koschel, R. Analysis of toxic aluminium species in natural waters. Microchim. Acta 2004, 146, 149-154. [CrossRef]

31. Cooke, G.D.; Welch, E.B.; Peterson, S.A.; Nichols, S.A. Restoration and Management of Lakes and Reservoirs, 3rd ed.; Taylor \& Francis/CRC Press: Boca Raton, FL, USA, 2005; p. 591.

32. Waters, A.S.; Webster-Brown, J.G. Assessing aluminium toxicity in streams affected by acid mine drainage. Water Sci. Technol. 2013, 67, 1764-1772. [CrossRef]

33. Barabasz, W.; Albińska, D.; Jaśkowska, M.; Lipiec, J. Ecotoxicology of Aluminum. Pol. J. Environ. Stud. 2002, 11, 199-203.

34. Cooke, G.D.; Welch, E.B.; Martin, A.B.; Fulmer, D.G.; Hyde, J.B.; Schrieve, G. Effectiveness of Al, Ca, Fe salts for control of internal phosphorus loading in shallow and deep lakes. Hydrobiologia 1993, 253, 323-335. [CrossRef]

35. Li, G.; Xie, F.; Zhang, J.; Wang, J.; Yang, Y.; Sun, R. Occurrence of phosphorus, iron, aluminum, silica, and calcium in a eutrophic lake during algae bloom sedimentation. Water Sci. Technol. 2016, 74, 1266-1273. [CrossRef] [PubMed]

36. Łopata, M.; Wiśniewski, G.; Brzozowska, R. Aluminum treatment of low alkaline lake waters buffered with calcium carbonate-laboratory investigations. Glob. J. Adv. Pure Appl. Sci. 2013, 1, 704-709.

37. Łopata, M. Restoration of Polymictic Lake Głeboczek in Tuchola with Phosphorus Inactivation Method. Ph.D. Thesis, University of Warmia and Mazury in Olsztyn, Olsztyn, Poland, 2005.

38. Łopata, M.; Gawrońska, H.; Jaworska, B.; Wiśniewski, G. Restoration of two shallow, urban lakes using the phosphorus inactivation method-preliminary results. Water Sci. Technol. 2013, 68, 2127-2135. [CrossRef] [PubMed]

39. McCormick, P.V.; Shuford III, R.B.E.; Chimney, M.J. Periphyton as a potential phosphorus sink in the Everglades Nutrient Removal Project. Ecol. Eng. 2006, 27, 279-289. [CrossRef]

40. Allen, E.D.; Spence, D.H.N. The differential ability of aquatic plants to utilize the inorganic carbon supply in fresh waters. New phytol. 1981, 87, 269-283. [CrossRef]

41. Berg, G.M.; Glibert, P.M.; Chen, C.C. Dimension effects of enclosures on ecological processes in pelagic systems. Limnol. Oceanogr. 1999, 44, 1331-1340. [CrossRef]

42. Cui, Y.; Jin, L.; Ko, S.-R.; Chun, S.-J.; Oh, H.-S.; Lee, C.S.; Srivastava, A.; Oh, H.-M.; Ahn, C.-Y. Periphyton effects on bacterial assemblages and harmful cyanobacterial blooms in a eutrophic freshwater lake: A mesocosm study. Sci. Rep. 2017, 7, 7827. [CrossRef] [PubMed] 